\title{
Perbawaslu Analysis Number 4 Year 2020 Concerning Resolution of Disputes of Regional Head Election in the Pandemic Time Covid-19
}

\author{
Dewi Iriani ${ }^{1}$, Martha Eri Safira ${ }^{2}$, Arief Budiono ${ }^{3}$ and Muhammad Noor ${ }^{4}$ \\ \{dewiiriani@iainponorogo.ac.id ${ }^{1}$, marthasafira82@gmail.com² ${ }^{2}$, areevahims@gmail.com ${ }^{3}$, \\ m_noor7474@yahoo.co.id $\left.{ }^{4}\right\}$
}

Shariah Faculty, IAIN Ponorogo, Indonesia ${ }^{124}$, Law Faculty, University Muhammadiyah Surakarta, Indonesia ${ }^{3}$

\begin{abstract}
The Covid 19 pandemic affects life from various aspects of life both economically and socio-culture which of course must adjust habits before the pandemic period. That is the case with the implementation of regional head elections (pilkada) that have taken place in 2020. There is still election fraud during the pandemic, of course the settlement of the dispute over Bawaslu Regulation Number 4 of 2020 concerning Supervision, Handling of Violations and Dispute Resolution for Election of Governors and Deputy Governors, Regents and Simultaneously, the Deputy Regent, Mayor and Deputy Mayor This policy was taken in relation to the corona virus pandemic (Covid19). For this reason, the authors will examine more deeply with the formulation of the problem 1) How is the formation of Bawaslu Regulation Number 4 of 2020 on NonDisaster Conditions Corona Virus Disease 2019 (Covid 19) based on statutory theory? 2) What is the legal policy in resolving regional election disputes in covid 19 conditions? This research is a descriptive analysis research with a normative legal research approach (legal research) in literature study. Results of discussion and analysis 1) Based on statutory theory, the basis for the formation of statutory regulations refers to a philosophical perspective; Bawaslu regulations have clear objectives to optimize and streamline the implementation of the duties, powers and obligations of election supervisors. juridical election dispute resolution no longer refers to law 7 of 2017 and and Perbawaslu 5 of 2019, but refers to Bawaslu Regulation Number 4 of 2020 concerning Supervision, Handling of Violations and Dispute Resolution for the Election of Governors and Deputy Governors, Regents and Deputy Regents, and Mayors and the Deputy Mayor simultaneously in the non-natural disaster condition of Corona Virus Disease 2019 (COVID-19). sociological aspect; thus, requiring rapid dispute resolution, which is done online or in person, must follow strict health protocols. 2). The legal policy taken by the government in suppressing the spread of the corona virus, according to the author, is very appropriate in the implementation and settlement of regional election disputes. In this case Bawaslu regulates; Election dispute resolution (Article 63 paragraph 1 to paragraph 3), acceptance of applications (Article 65 and Article 67), Deliberation in dispute resolution (Article 68, Article 69 and Article 70), Decision on election dispute settlement as in Bawaslu Regulation Number 4 of 2020 regarding Supervision, Handling of Violations and Dispute Resolution for the Election of Governors and Deputy Governors, Regents and Deputy Regents, as well as Mayors and Deputy Mayors simultaneously in Non-Disaster Conditions Corona virus Disease 2019 (Covid 19).
\end{abstract}

Keywords: Regional Head Election; Dispute Resolution; Perbawaslu 


\section{Introduction}

Cholera, bubonic plague, influenza were serious epidemics in the past in the Indonesian nation as a contagious disease in the 19th century, which began when pilgrims from Saudi Arabia passed through the sea route (1). not only cholera, bubonic plague and influenza, there are diseases carried by rats brought about by rice imports from Myanmar (2). In the early 20th century, Indonesia was known as the Dutch East Indies as the center of maritime trade with European countries (3). A recurrence of the plague again after many centuries, reappearing in December 2019 starting from the Chinese Wuhan market. The corona virus outbreak spreads throughout the world including in Indonesia in March 2020, another name for the Corona virus, also known as Covid 19 (4). Coronavirus / Coronavirus people who are affected from without symptoms, mild, moderate, severe and even death such as the Middle East Respiratory Syndrome (MERS) and severe acute respiratory syndrome (SARS) viruses, Coronavirus The virus that causes COVID-19 is called Sars-CoV-2 (5).

Covid 19 has different characteristics with other types of epidemic diseases such as cholera, bubonic plague, influenza, avian flu, and others. Covid 19 not only causes pain for the sufferer, but has a wider impact on people who have had direct contact with the sufferer, it will spread very quickly and widely. For those suffering from COVID-19 who are positive in the severe category, incentive treatment will be carried out in the hospital. For those with moderate, mild or asymptomatic reactive isolation at home, this requires the government to make rules for the community to do $3 \mathrm{~m}$; keep your distance, wash your hands, wear a mask (6).

The government in dealing with the prevention of covid 19 made several rules including; Presidential Decree No. 11/2020 concerning Determination of Public Health Emergencies for Corona Virus Disease 2019 (COVID-19), Perpu Number 1 of 2020 concerning State Financial Policy and Financial System Stability for Handling Pandemic Corona Virus Disease 2019 (COVID-19) and / or in the context of Facing Threats Endanger the National Economy and / or Financial System Stability; Government Regulation Number 21 of 2020 concerning LargeScale Social Restrictions in the Context of Accelerating the Management of Corona Virus Disease 2019 (COVID-19), Circular No. 57/2020 28 May 2020 concerning the Extension of Work From Home (WFH) for State Civil Servants (ASN) until 4 June 2020; Presidential Decree (KEPPRES) No. 12 of 2020 concerning the Determination of Non-Natural Disaster for the Spread of Corona Virus Disease 2019 (COVID-19) as a National Disaster, and others.

President Jokowi Widodo on April 17, 2020 the President announced COVID-19 as a national disaster through Presidential Decree No. 12 of 2020, the number of coronavirus cases continues to increase in number. As of June 17, 2020, the total number of positive corona cases in Indonesia has reached 40,400, 15,703 patients who have recovered, and 2,231 patients who have died (7). The increasing spread of Covid 19 evenly throughout the territory of Indonesia requires the government to take policy steps such as: restrictions on people gathering in public places, restrictions on passengers on vehicles, use of personal protective equipment for health workers, work and schooling at home, social restrictions, prohibition of carrying out celebrations marriage, the government can prepare good policy schemes to prevent and overcome the impact that the Corona virus has on society, so far the government is considered successful in carrying out its function as good government and good governance. governance) in the era of the COVID-19 pandemic (8).

The Covid 19 pandemic affects life from various aspects of life both economically and socio-culture which of course must adjust habits before the pandemic period. Likewise with the implementation of the regional head elections (pilkada) which have taken place in 2020. 
The constancy of the pandemic era elections is still carried out directly but of course it adapts to the Covid 19 pandemic, where the implementation of the elections is carried out by implementing health protocols. With the imposition of restrictions on the attendance of election participants and the application of health protocols, this does not reduce the occurrence of fraud in the implementation of the 2020 elections.

Quoted from MK and KPU data online Wednesday, December 23, 2020 at 16.00 WIB. that the Constitutional Court (MK) has received 131 applications for the 2020 Pilkada General Election Result Dispute (PHPU). Most of the petition reports were related to Regent election, 114 applications for PHPU, and mayoral election there were 14 applications. In the 2020 Regional Head Election (Pilkada), 3 lawsuits were submitted to the MK. This is stated in the recap of submission of Election Result Dispute (PHP) for the Governor, Regent and Mayor. (9) (10)

Pandemic era, of course, election fraud over reports of requests for submission of Election Result Disputes (PHP) for Governors, Regents and Mayors in dispute resolution is regulated in Bawaslu Regulation Number 4 of 2020 concerning Supervision, Handling of Violations and Dispute Resolution for Election of Governors and Deputy Governors, Regents and Deputy Regent, Mayor and Deputy Mayor simultaneously. Non-Disaster Conditions Corona Virus Disease 2019 (Covid 19), namely by resolving the 2020 Regional Election disputes through an information technology system or through a network (online). This policy was taken in connection with the corona virus pandemic (Covid-19).

For this reason, the authors will examine more deeply related to regional election dispute resolution in non-natural conditions of corona virus disease 2019 (Covid 19) with problem formulations 1) How is the formation of Bawaslu Regulation Number 4 of 2020 in NonNatural Disaster Conditions Corona Virus Disease 2019 (Covid 19) based on statutory theory? 2) What is the legal policy in resolving regional election disputes in covid 19 conditions?

\section{Method}

This research is a descriptive analysis research with a normative legal research approach (legal research) in the literature study in the form of books, articles, journals related to statutory theory and legal theory of public policy which is linked to Regulation Number 4 of 2020 concerning Supervision, Handling of Violations and Dispute Resolution for the Election of the Governor and Deputy Governor, the Regent and Deputy Regent, as well as the Mayor and Deputy Mayor simultaneously in the non-natural conditions of the corona vius disease 2019 (Covid 19). As for the purpose of this research, it is to examine in detail in Regulation Number 4 of 2020, the settlement of regional election disputes in covid 19 conditions in terms of statutory theory and legal theory of public policy.

\subsection{Establishment of Legislation in Bawaslu Regulation Number 4 of 2020 Settlement of Election Disputes in Non-Natural Disaster Conditions of Corona Virus Disease 2019 (Covid 19)}

Before stepping on to study the results of the analysis of Bawaslu regulation number 4 of 2020 for the settlement of regional election disputes in the non-natural conditions of the corona virus disease 2019 (Covid 19), the authors will study in theory the formation of legislation first. Maria Farida Indrati Soeprapto explained where is the definition of legislation in terms of the meaning of wetegeving in Juridisch woordenboek as the process of forming 
central and regional legislation, legislation Definition, gesetgebung means legislation, the meaning of legislation is defined as legislators (11).

S.J. Fockema Andreae said that written rules that are generally binding and made by authorized officials through the procedures stipulated in statutory regulations are the result of the formation of regulations, both at the central and regional levels. (12). Behavioral rules which contain provisions regarding rights, obligations, functions, status or an order issued by an authorized official or office environment. Has general and abstract characteristics, does not regulate certain concrete objects / events / symptoms as conveyed by Prof Bagir Manan (13).

The form of regulations called "beleids regels" (policy rules) is usually translated into Indonesian into policy regulations which are often referred to as quasi regulations. There are three (3) types of legal norms that are the result of the legal decision-making process, namely: normative decisions that are regulating (regaling); normative decisions that are administrative (beschikking); a normative decision called a vonis (14). Then according to Sajipto Raharjo, laws and regulations have characteristics; General and comprehensive, specific and limited, universal. That is, regulations will be made when an event has occurred which requires a rule in the form of legislation by including a clause that regulates (15).

Well, the writer will continue with the analysis related to Bawaslu regulations as follows; General elections are very necessary for the continuity of progress in a region, so it requires the leadership of the regional head, namely the Governor, Regent, Mayor. However, this general election is very different from the general election in the previous year. Where the 2020 general election was carried out with physical distancing, as the KPU regulates the General Election by issuing a General Election Commission Regulation. PKPU No. 05 of 2020 concerning the third amendment to the general election commission regulation No. 15 of 2019 concerning Stages, Programs and Schedule for Organizing the Election of Governors and Deputy Governors, Regents and Deputy Regents, and Mayors and Deputy Mayors in 2020 with supervision of health protocols so that the implementation of the General Election will not cause problems in the future

Likewise, the settlement of election disputes will be different in the previous year, where the settlement of election disputes is carried out through the online network system as regulated in Bawaslu Regulation Number 4 of 2020 on Non-Disaster Conditions Corona Virus Disease 2019 (Covid 19) based on the principle of establishing legislation as contained in Article 45 and Article 49.

Article 45 states that the implementation of Violation Management assistance is carried out with due observance of the health protocol for prevention and control of COVID-19 as referred to in Article 3 and Article 4 or it can be done through online-based information and communication technology. Likewise, Article 49 of the Provincial Bawaslu has the authority to receive, examine, and decide on the handling of administrative violations in a structured, systematic, and massive manner in the implementation of Continuous Elections conducted face-to-face and / or through online-based information and communication technology. (16).

Every regulation that has been passed, automatically the community must implement the regulation without exception. No one says they do not know there are regulations, if the statutory regulations have been passed and are valid in the community. Similar regulations apply the principle of "lex posterior derogate legi anteriori" general law is equally specific, while what is regulated later is general, so the principle of "legi special per generalum non deregatur" applies. The explanation of the statutory regulations can be determined for a period of time but cannot be implemented because the implementing regulations do not yet exist.

As for the enactment of a regulation, seen from the regulation itself, if it states "the regulation applies from the date ... to the date ..." or another regulation is determined, issue it 
later, usually first. Regarding the expiration of regulations, new regulations can be made by "repeal the regulations that are in conflict with the new law. "Withdrawal of regulations if the regulations have the same degree, the regulations can be changed / revoked only with regulations with the same or high degree of hierarchy. If there are regulations, then regulations with a lower degree are made. Then the first rule remains in effect, if what is made later has a higher level, then the first is null and void according to law. (17)

The meaning in the content of statutory regulations contains the types and hierarchy of statutory regulations, as stipulated in Law No. 15 of 2019 concerning Amendments to Law 12 of 2011 concerning the Formation of Laws and Regulations Article 1. The content of article 1 on the formation of statutory regulations Legislation is the making of Legislation which includes the stages of planning, preparation, discussion, ratification or stipulation, and promulgation. Legislation is a written regulation that contains legally binding norms and is established or stipulated by a state institution or authorized official through the procedures stipulated in the Legislation (18).

The types and hierarchy of the 1945 Constitution of the Republic of Indonesia; Laws / Government Regulations in Lieu of Laws; Government regulations; Presidential decree; Regional Regulations (province, district, village) (19) So that the authors will analyze the issuance of the formation of Bawaslu regulation Number 4 of 2020 in the Non-Natural Conditions of Corona Virus Disease 2019 (Covid 19).

a. A law is no longer valid, if the validity period has been determined by past law, the circumstances or things for which the law no longer applies, the law is expressly repealed by the agency that made it or a higher agency. There has been a new law whose contents contradict or differ from the previous law. The author will further explain the laws and regulations related to elections; The implementation of the General Election is regulated in Law No.7 of 2017. While the implementation of the Pilkada is regulated in Law No.1 of 2014 concerning the Election of Governors, Regents and Mayors where the implementation of this law has experienced turmoil in the community in terms of regional head elections being elected by DPRRI. Then it was changed to Stipulation of Government Regulation in Lieu of Law (perpu) No. 1 of 2015 which subsequently became law No. 8 of 2015. Thus, Law No. 1 of 2014 and Perpu No. 1 of 2015 is no longer valid. Furthermore, in 2020 the government issued a Third Amendment to Law Number 1 of 2015 concerning Stipulation of Government Regulations in Lieu of Law Number 1 of 2014 concerning the Election of Governors, Regents and Mayors into Law 6 of 2020 .

Automatically, the implementation of the pilkada refers to Law No. 6 of 2020. KPU and Bawaslu are the organizers of the election in 22/2007. Both the election laws and the election management laws regulate the mechanism and process of dispute resolution as regulated in articles 466 to 469 of law 7 of 2017 and in more detail are regulated by Perbawaslu 5 of 2019 concerning procedures for resolving disputes in the General Election process. In 2020 the covid outbreak attacks all regions of Indonesia, so for the settlement of election disputes is regulated in Bawaslu Regulation Number 4 of 2020 concerning Supervision, Handling of Violations and Dispute Resolution for Election of Governors and Deputy Governors, Regents and Deputy Regents, as well as Mayors and Deputy Mayors simultaneously Non-Natural Disaster Corona Virus Disease 2019 (Covid 19)

b. Terms of Applicability of Law. A law can be enforced, it must fulfill the following requirements for the enactment of the law: According to the date set forth in the law itself If the date is not stated in the law, then the law is effective as of 30 days after it is 
promulgated in a sheet state (applies to Java and Madura) For other regions, it only takes effect after 100 days of promulgation in the state sheet and all the requirements have been met.

The author argues that the Covid 19 outbreak will easily spread, if the implementation of electoral dispute resolution is carried out directly with a large gathering of people. then to decide / prevent the formation of a new clause for resolving election disputes, refer to Bawaslu Regulation Number 4 of 2020 concerning Supervision, Handling of Violations and Dispute Resolution for the Election of the Governor and Deputy Governor, the Regent and Deputy Regent, as well as the Mayor and Deputy Mayor simultaneously. Thus, for the settlement of election disputes it no longer refers to law 7 of 2017 and and Perbawaslu 5 of 2019

c. The enforceability of laws: a law is binding since it is promulgated, meaning that since then people are obliged to acknowledge the existence of the law. Meanwhile, the strength of a law means that it is related to the operation of the law operationally. In order for a law to have the force to apply it must meet the following requirements: Strength applies philosophical, juridical, sociological, according to Burkhardt Krems, that is one of the major parts of the science of legislation. According to Burkhardt Krems, that one of the major parts of statutory science is legislation theory (Gestzgebungstheorie) which is oriented towards seeking clarity and clarity of meaning or cognitive understanding application, enforcement, and understanding of the law, including the substance of the law or the content of laws and regulations. Therefore, so that the resulting legislation can reflect good quality as a legal product, it is necessary to understand some of the basic foundations of the formation of laws and regulations in terms of philosophy, juridical and sociological. (20).

So that the Bawaslu regulations from a philosophical, juridical and sociological point of view can be explained in more detail. From a philosophical point of view; The Bawaslu regulation has clear objectives to optimize and streamline the implementation of the duties, powers and obligations of the Supervisors for the Election of Governors and Deputy Governors, Regents and Deputy Regents, as well as Mayors and Deputy Mayors. disputes on the holding of the Election for the Governor and Deputy Governor, the Regent and Deputy Regent, as well as the Mayor and Deputy Mayor simultaneously continue in the non-natural disaster conditions of Corona Virus Disease 2019 (COVID-19); health and safety aspects as referred to in subsection (1) cover at least: application of the principles of occupational safety and health.

From a juridical perspective; Law Number 1 of 2015 concerning Stipulation of Government Regulations in Lieu of Law Number 1 of 2014 concerning Elections of Governors, Regents and Mayors into Law. As amended several times, most recently by a Government Regulation in Lieu of Law Number 2 of 2020, concerning the Third Amendment to Law Number 1 of 2015 concerning Stipulation of Government Regulations in Lieu of Law Number 1 of 2014 concerning Election of Governors, Regents and Mayors into Laws. Law Number 7 of 2017 concerning Election of General Election Supervisory Agency Regulation Number 1 of 2020 concerning Work Procedures and Relationship Patterns of the General Election Supervisory Agency, as amended by Number 4 of 2020 concerning Election Supervisory Agency Regulations

From a sociological point of view; to adjust to life with the Covid 19 pandemic. The Pilkada democracy party, will be held simultaneously in several regions in Indonesia on December 9, 2020, according to current conditions. As a result, in several stages of elections, 
campaigns and so on which are conducted online or face-to-face must follow strict health protocols. There is a new pattern in elections. This area can indirectly lead to disputes, thus requiring a quick resolution. Therefore, the Election Supervisory Agency (Bawaslu) issued Bawaslu Regulation Number 4 of 2020 concerning Supervision, Handling of Violations and Dispute Resolution for the Election of Governors and Deputy Governors, Regents and Deputy Regents, as well as Mayors and Deputy Mayors simultaneously in Non-Corona Vius Natural Disaster Conditions. Disease 2019 (Covid 19) through an online network system

\subsection{Legal Policy in The Settlement of Pilkada Disputes in Covid 19 Conditions Through Information and Communication Technology Based on The Legal Policy for Settlement of Disputes in The Condition of Covid 19 Through Information and Communication Technology}

Quoted from Kompas.com that there are still disputes over 2020 election fraud, Akhyar Nasution-Salman Alfarisi further published. Defeated by Bobby Nasution-Aulia Rachman, also among those who filed a lawsuit. Papua and North Sumatra are the provinces with the greatest number of candidate pairs, which submit disputes over the results of the regional elections. At least 13 couples in each of these regions have filed a dispute. This was followed by West Papua and North Maluku, each with nine disputes. Then there are Southeast Sulawesi and West Sumatra, with seven disputes each.

Regarding the governor-vice governor candidate pair, those who filed a dispute included Denny Indrayana-Difriadi in South Kalimantan, Ben Brahim-Ujang Iskandar in Central Kalimantan, Nasrul Abit-Indra Catri and Mulyadi-Ali Mukhni in West Sumatra and several other provinces. At the city level, Tangsel Pilkada candidate Muhamad Rahayu Saraswati filed a dispute. Machfud candidate pair Arifin-Mujiaman in Surabaya, and Akhyar NasutionSalman Alfarisi also submitted a dispute to the Constitutional Court. Those who file a dispute over the results of the election to the Constitutional Court generally think that there are practices of fraud and violations of a structured, systematic and massive nature (21).

Furthermore, the Executive Director of the Indonesian Democratic (IDE) Center, C. David Kaligis, predicted that cheating will flourish if the 2020 Pilkada is still held during the corona virus (Covid-19) pandemic. David said the pandemic limited the movement of organizers and the community during the regional elections. This provides an opportunity for individual candidates to commit fraud. David said that the potential fraud was mobilizing state apparatus, using state facilities, money politics, and marking up votes in the vote recapitulation process. It is known that vote recapitulation was carried out in stages. Starting from the TPS, sub-district, district / city level to the province for the election of the governor. The long process will provide an opening for cheating to be carried out. Moreover, the public will be limited in their space in the midst of a pandemic so that they have the potential to be unable to oversee the count (22).

December 2019, the corona outbreak hit Wuhan China, spreading to Indonesian territory since the beginning of March 2020, causing similar illnesses and deaths. So that Corona Virus Disease 2019 (COVID-19) has been designated as a public health emergency based on Presidential Decree No.11 of 2020 concerning the Determination of Corona Virus Disease 2019 Public Health Emergencies (COVID-19) and is a non-natural disaster designated as a non-natural national disaster. Likewise with the implementation of the pilkada and the completion of the regional head election with the issuance of the Regulation of the Minister of Foreign Affairs Number 4 of 2020 through an online or face-to-face network system with very strict health protocols. 
Various pilkada problems as described above, show that there are still many democratic agendas that we have to solve, both in terms of regulations, institutions and law enforcement. Election, is actually a very civilized process in selecting leaders and state regulators. However, because elections are a mechanism to choose who will be in power, it is difficult to avoid conflicts of interest and even lead to violence that can damage the noble goals of democratic choices. Therefore, a legal rule is needed (23): Jurnal Ilmu.

Mochtar Kusumaatmadja views that law regulates human life in society, which requires institutions (institutions) and processes (processes) as a set of rules and principles containing three conditions; First, a set of rules and principles. Second, legal structure institutions such as law enforcement agencies; police, prosecutors and courts. Third, the process of realizing legal principles and principles by law enforcement agencies. (24)

It is necessary to have a legal policy in the state administration formally so that it is fully enforceable which is binding and compelling. Because good law is required Policy making is needed to achieve common goals based on Pancasila and the 1945 Constitution. In addition, in the framework of implementing these policies (policy executing), law is functioned as a means of carrying out all wheels of government and state administration activities. (25) Context of policy making (policy making) and policy implementation (policy executing), for 11 years post-reform. In terms of the basic norm system, in the constitution of a country that is undergoing fundamental changes. In terms of material, it can be said that the 1945 Constitution has experienced from its original contents as inherited from 1945. As a consequence of this, the entire system of legal norms as reflected in various laws and regulations must also be amended and updated. (26).

Its relationship with public policy instruments shows that the function of modern law is examined from Satjipto Rahardjo's opinion. The function of modern law is not only to record people's behavior patterns, but rather a means of policies that create new conditions or change something that already exists. (27). As stated by A. Hoogerwer In order to achieve these policy objectives, instruments or means are needed (28). B.G. Peters identified several types of policy instruments, namely: law / statute; service, money; tax; economic instruments (29)..

Government officials need legal policies in the form of laws, other regulations to regulate public behavior in the interests of society needed. In its legitimacy, namely: The need to govern, demands for legitimacy, legal form, legal system, policy strata and hierarchy of laws and regulations, public policy approach in law enforcement legal processes, value systems in public policy, ethics of public policy or public policy. (30)

The contents of a law cannot be separated from the policy of administering the authority of government officials, namely it is also known as the policy regulation of the authorized official "not bound" to any person. (31). What is meant by administering "unbound" government authority is that it is not strictly regulated by statutory regulations on data, information, or thoughts and suggestions as a source of public policy making. Various decisions or legal products that have a higher legal status or hierarchy of decisions or policies (32).

Health has been instructed by the Central Government so that it is truly safe and does not cause problems after the regional head election. This of course also has to pay attention to the local conditions of the regions that will undergo Pemilukada related to how the spread of Covid-19 in the area so that it can be prepared properly and optimally to reduce risks (33).

The legal policy taken by the government in suppressing the spread of the corona virus, according to the author, is very appropriate in the implementation and resolution of regional election disputes. In this case Bawaslu regulates; Election dispute resolution (Article 63 paragraph 1 to paragraph 3), acceptance of applications (Article 65 and Article 67), 
Deliberation in dispute resolution (Article 68, Article 69 and Article 70), Decision on election dispute settlement as in Bawaslu Regulation Number 4 of 2020 regarding Supervision, Handling of Violations and Dispute Resolution for the Election of Governors and Deputy Governors, Regents and Deputy Regents, as well as Mayors and Deputy Mayors simultaneously in the Non-Disaster Conditions of Corona virus Disease 2019 (Covid 19), namely

a. Election dispute resolution; simultaneous regional elections of Province, Regency / City, District. must implement health protocols implemented through face-to-face meetings and / or through online-based information and communication technology. Bawaslu by providing facilities, safe distance to physical contact, masks and gloves, temperature measuring devices without physical contact, hand washing stations with running water and soap.

b. Acceptance of applications and registration of applications; The applicant submits application documents in the form of applications, written evidence, and other documents. carried out through face-to-face meetings at the application reception counter or via the SIPS page. The plenary meeting for the acceptance and examination of documents and registration of applications must be carried out by following standard health protocol procedures.

Deliberation in the settlement of Pilkada disputes; local government policies regarding the spread of COVID-19 in the Provincial Bawaslu or Regency / City Bawaslu areas. Facing arrangement by applying a capacity limit for the number of people at most $50 \%$, maintaining distance by adjusting the number and position of tables and chairs in the deliberation room; checking body temperature conditions without physical contact before entering the deliberation room, social restrictions and physical contact restrictions; by implementing standards for the delivery and storage of physical documents. Meanwhile, deliberation through online networks ensures the readiness and availability of supporting facilities and infrastructure in the form of: television or projector; stable internet network; and supporting software; d. parties in the deliberation confirm attendance to the Provincial Bawaslu or Regency / City Bawaslu to ensure the readiness and readiness of publication facilities and infrastructure to the public for the implementation of open deliberations.

c. The reading of election dispute decisions can be carried out through face-to-face or online-based information and communication technology. implemented by means of online-based information and communication technology, the deliberative assembly is obliged to notify the parties.

\section{Conclusion}

Based on statutory theory, the basis for the formation of statutory regulations refers to a philosophical perspective; Bawaslu regulations have clear objectives to optimize and streamline the implementation of the duties, powers and obligations of election supervisors. juridical election dispute resolution no longer refers to law 7 of 2017 and and Perbawaslu 5 of 2019, but refers to Bawaslu Regulation Number 4 of 2020 concerning Supervision, Handling of Violations and Dispute Resolution for Election of Governors and Deputy Governors, Regents and Deputy Regents, and The Mayor and Deputy Mayor simultaneously are in a disaster condition without the Corona Virus Disease 2019 (COVID-19). sociological aspect; 
thus, requiring rapid dispute resolution, which is done online or in person, must follow strict health protocols.

Legal policies taken by the government in suppressing the spread of the corona virus, according to the author, are very appropriate in the implementation and settlement of regional election disputes. In this case Bawaslu regulates; Election dispute resolution (Article 63 paragraph 1 to paragraph 3), acceptance of applications (Article 65 and Article 67), Deliberation in dispute resolution (Article 68, Article 69 and Article 70), Decision on election dispute settlement as in Bawaslu Regulation Number 4 of 2020 regarding Supervision, Handling of Violations and Dispute Resolution for the Election of Governors and Deputy Governors, Regents and Deputy Regents, as well as Mayors and Deputy Mayors simultaneously in the Non-Disaster Conditions of Corona Virus Disease 2019 (Covid 19).

Settlement of regional head election disputes is expected to be carried out online, even if face-to-face must strictly follow health protocols to decide the spread of Covid 19 in accordance with Bawaslu Regulation Number 4 of 2020. The legal policy stipulated that the settlement of local election disputes in Bawaslu should be implemented by all parties, namely, the applicant, the respondent, the judge, the attorney, the Bawaslu, the KPU.

\section{References}

[1] Eric T. Pilgrim Ships and the Frontiers of Contagion: Quarantine Regimes from Southeast Asia to the Red Sea" dalam Tim Harper and Sunil S. Amrith (ed), Histories of Health in Southeast Asia Perspectives on the Long Twentieth Century.: Indiana University Press; 2014.

[2] Thamrin MY. nationalgeographic.grid.id. [Online]. [cited 6 Januari 2021. Available from: https://nationalgeographic.grid.id/read/132090830/karut-marut-pagebluk-pes-pertama-di-hindiabelanda//.

[3] Oomgaard. The Development of Colonial Health Care in Java: An Exploratory Introduction Bijdragen tot de Taal-, Land- en Volkenkunde, Deel 149, 1ste Afl; 2019.

[4] ifsw.org. [Online]. [cited 21 Januari 2021. Available from: FSW. Statement on IFSW and COVID19". https://www.ifsw.org/statement-onifsw-and- covid-19.

[5] Direktorat Jenderal Pencegahan dan Pengendalian Penyakit, Kementerian Kesehatan RI. www.Kemeterian Kesehatan RI.go.id. [Online].; 2020 [cited 22 Januari 2021. Available from: www.Kemeterian Kesehatan RI.go.id.

[6] Satria A. Peran Kampus di Masa Pandemi Covid-19: Laporam Khusus Inovasi Pendidikan Melawan Corona. Kusut Bantuan Sosial. Program Jaring Pengaman Sosial Untuk Meredam Dampak COVID19 Acak-acakan, Tumpang tindih, dan Salah Sasaran Akibat Data Amburadul. 2020 Mei.

[7] Firmansyah R. Tribunjogja.go.id. [Online]. [cited 22 Januari 2021. Available from: www.Tribunjogja.go.id.

[8] Tuwu D. Kebijakan Pemerintah Dalam Penanganan Pandemi Covid-19 Jurusan Ilmu Kesejahteraan Sosial Fisip Universitas Halu Oleo. Journal Publicuho. 2020 May-July; 3(2): p. 267-278.

[9] Mahkamah Konstitusi. MK.go.id. [Online]. [cited 23 Januari 2021. Available from: www.MK.go.id.

[10] Komisi Pemilihan Umum. KPU.go.id. [Online]. [cited 2021 Januari 25. Available from: www.KPU.go.id.

[11] Soeprapto MFI. Ilmu Perundang-undangan Yogyakarta: Kanisius; 2017.

[12] Andreae SJF. Ilmu Perundang-undangan Yogyakarta: Kanisius; 2007.

[13] Manan B. Ilmu Perundang-undangan Yogyakarta: Kanisius; 2017.

[14] Sulaiman KF. Teori Peraturan Perundang-undangan dan Aspek Pengujiannya Yogyakarta: Thafa Media; 2017.

[15] Rahardjo S. Ilmu Hukum Bandung: PT Citra Aditya; 2019.

[16] Pemerintah Republik Indonesia. Peraturan Nomor 4 Tahun 2020 tentang Pengawasan, Penanganan Pelanggaran dan Penyelesaian Sengketa Pemilihan Gubernur dan Wakil Gubernur, Bupati dan 
Wakil Bupati, serta Walikota dan Wakil Walikota Secara Serentak Jakarta: Lembaran Negara republik Indonesia; 2020.

[17] Iriani D. Pengetahuan Ilmu Hukum Dan Pengenalan Tentang Hukum Di Indonesia Ponorogo: CV. Senyum Indonesia; 2016.

[18] Pemerintah Republik Indonesia. UU 15 tahun 2019 tentang Perubahan Atas UU 12 tahun 2011 tentang Pembentukan Peraturan Perundang-Undangan Jakarta: Lembaran Negara Republik Indonesia; 2019.

[19] Pemerintah Republik Indonesia. Undang-Undang No. 10 tahun 2004) tentang Peraturan Perundangundangan Jakarta: Sinar Grafiks; 2005.

[20] MD MM. Membangun Politik Hukum, Menegakan Konstitusi Jakarta: Raja Grafindo Persada; 2020.

[21] Shalihah NF. www.Kompas.com. [Online]. [cited 2021 Januari 23.

[22] Kaligis CD. www.CNN Indonesia. [Online]. [cited 2021 Januari 23.

[23] Zoelva H. Problematika Penyelesaian Sengketa Hasil Pemilukada oleh Mahkamah Konstitusi. Jurnal Konstitusi. 2018 September; 10(3): p. 39.

[24] Kusumaatmadja M. Hukum, Masyarakat dan Pembinaan Hukum Nasional Bandung: Lembaga Penelitian Hukum dan Kriminologi Fakultas Hukum Universitas Padjadjaran; 2018.

[25] Asshiddiqie J. Negara Hukum Indonesia. Ceramah Umum. 2017 Januari 23.

[26] Asshiddiqie J. Konstitusi \& Konstitusionalisme Indonesia Jakarta: Sekretariat Jenderal dan Kepaniteraan Mahkamah Konstitusi RI; 2016.

[27] Rahardjo S. Hukum dan Perubahan Sosial Bandung: Alumni; 2019.

[28] Hoogerwerf A. Isi dan Corak-Corak Kebijaksanaan dalam Ilmu Pemerintahan Jakarta: Erlangga; 2019.

[29] Parsons W. Public Policy: Pengantar Teori dan Praktik Analisis Kebijakan Jakarta: Kencana; 2020.

[30] Seidman A, B R, Seidman , Abeyserkere N. Penyusunan Rancangan Undang-Undang Dalam Perubahan Masyarakat Yang Demokratis Sebuah Panduan Untuk Pembuat Rancangan UndangUndang Jakarta: ELIPS Departemen Kehakiman dan Hak Asasi Manusia; 2018.

[31] A HSA. Hukum Tentang Peraturan Perundang-undangan dan Peraturan Kebijakan (Hukum Tata Pengaturan) Depok: UI; 1993.

[32] Wignjosoebroto S. Keragaman dalam Konsep Hukum, Tipe Kajian, dan Metode Penelitiannya Bandung: Refika Adita.

[33] Hilman YA, Khoirurrosyidin , Lestarini N. Politik Pemilukada Kabupaten Ponorogo 2020 di Tengah Pandemi COVID-19Regional Election in Ponorogo Regency: Political Map in The Middle COVID-19 Pandemic. Jurnal Ilmu Politik. ; 2(2) 